\title{
EFFECT OF BEETROOTS SUBSTITUTION AND STORAGE ON THE CHEMICAL AND SENSORY PROPERTIES OF WHEAT NOODLES
}

\author{
${ }^{*}$ Abiodun, O.A, ${ }^{2}$ Ojo, A., ${ }^{1}$ Abdulganiu, O. S. and ${ }^{2}$ Olosunde, O.O. \\ ${ }^{1}$ Department of Home Economics and Food Science, University of Ilorin, Ilorin, \\ ${ }^{2}$ Department of Food Science and Technology, Osun State Polytechnic, Iree. \\ *Corresponding Author: funmiabiodun2003@yahoo.com
}

\begin{abstract}
Beetroot consists of betalain, a natural red pigment which has desirable biological activities such as antioxidant, mineral and anti-inflammatory properties. Substitution of wheat flour with beetroot flour could improve the aesthetic and nutritional properties of the product. This study was conducted to determine the effects of beetroots substitution and storage on the chemical and sensory properties of wheat noodles. The noodles were prepared with beetroot powder of $5 \%, 10 \%, 15 \%$ and $100 \%$ wheat flour which serve as the control. Progressive decrease in lightness value was observed from 51.98 to 46.76 with increase in level of beetroot powder. The colour* value of control noodle was 1.13 and those of beetroot powder increased from 5.12 to 9.47 , showing more reddish colour than the control. There were increase in redness $\left(a^{*}\right)$ value and decrease in lightness ( $\left.L^{*}\right)$ value with the increase of colouring pigments. At the third months of storage, the noodles became lighter losing the red colouration. No significant differences $(p<0.05)$ in the protein contents of the noodles. The betalain contents of the noodles increased with beetroot substitution and decreased with storage. Cooking loss and swelling power of the noodles increased with increase in beetroot powder substitution. The antioxidant potential of the noodles increased with increase in beetroot powder with $15 \%$ having the highest value $(39.22 \%)$ while the value decreased with storage. The sensory result showed that the appearance of the control noodles was more preferred and accepted than others.
\end{abstract}

Keywords: Noodles, Betalain, Storage, Colour, Antioxidant 


\section{INTRODUCTION}

Instant noodle meal is popular and acceptable to children and adult in Nigeria and world at large (Animashahun et al., 2018). Acceptability of noodles led to great explosion of noodles industries worldwide. This increase in utilization of noodles is due to its accessibility, convenience and affordability (Dhiraj and Prabhasankar, 2013). Nooraziah and Komathi (2009) also observed that substitution of wheat flour for noodle production kept on increasing due to the growing market for confectioneries. Substitution of wheat flour with indigenous crops had been reported to increase the utilization of the crop (Sanni et al., 2004). Hou and Kruk (1998) described different types of noodles with different ingredients and that the processing involved are mixing raw materials, dough sheeting, compounding, sheeting/rolling and slitting. Lots of noodles had been made by researchers using different raw materials to substitute wheat flour. Among the raw materials used were sweet potato, cassava, yellow trifoliate yam, carrot etc (Taneya et al., 2014; Omeire et al., 2015; Abiodun et al., 2017; Abiodun et al., 2018). Authors had reported positive results in the noodles produced due to substitution of wheat flour with indigenous crops. These positive results observed are also due to the percentage of the blending of the composite flour (Noorfarahzilah et al., 2014).

Beetroot (Vulgaris ruba L.) is a crop belonging to the family Chenopodieacea and it is an excellent source of red and yellow pigments. It had been reported that red beetroot has high concentration of betalain which are used as food colourants and food additives (Kathiravan et al., 2015). Betalain impact attractive colour to food products and have been shown to confer free-radical scavenging and antioxidant activities. Therefore, this paper presents the effect of beetroot substitution and storage on the chemical and sensory properties of wheat noodles.

\section{MATERIALS AND METHODS}

Fresh beetroots were purchased in Bukuru market in Jos, Plateau State, Nigeria. Wheat flour, salt, and potatoes were purchased at Tanke, Tipper Garage, Ilorin, Kwara State. Beetroots were washed, peeled, sliced, dried in a dehydrator at 50 ${ }^{\circ} \mathrm{C}$ and then milled into powder using a blender. The beetroot powder was sieved with $600 \mu \mathrm{m}$ mesh size. Wheat flour was substituted with different proportions of beetroot powder $(5,10$, and $15 \%)$. Four noodle samples were prepared by substituting wheat flour with $0 \%, 5 \%, 10 \%, 15 \%$, of beetroot powder. All the ingredients were weighed in right proportion into the extruder (Propelli pasta 
maker) and allowed to mix properly with water before the extrusion process begins. The noodles were dried and packaged in polyethylene bags.

\section{Analyses}

Proximate composition was done using Association of Official Analytical Chemist (AOAC, 2010) while the colour was determined using method of Oyeyinka et al., (2019), betalain and antioxidant properties was done according to Ravichandran et al., (2013) methods. Cooking qualities was done using American Association of Cereal Chemists (AACC, 2000) method. Sensory evaluation was carried out using nine-point Hedonic scale.

\section{Statistical Analyses}

The procedure was done in triplicate and data obtained were subjected to analysis of variance (ANOVA) to determine the mean, standard deviation and significant differences among the samples $(p<0.05)$ and the means were separated using Duncan multiple range test as packaged by SPSS (ver. 17).

\section{RESULTS AND DISCUSSION \\ Effect of Storage on the Colour of Beetroot Noodles}

Table 1shows the effect of beetroot powder on the colour of wheat noodles. Noodles with $5 \%$ and $10 \%$ beetroot powder were lighter (higher $L$ ) than noodles with $15 \%$ beetroot powder. Progressive decrease in lightness value was observed from 51.98 to 46.76 with increase in level of beetroot powder. A reduction in $L^{*}$ value of noodles showed low luminosity, brightness and subsequently darker appearance of noodles (Chhikara et al., 2018). The $a^{*}$ value of control noodle was 1.13 and those of beetroot powder was increased from 5.12 to 9.47 , showing more reddish colour than the control. There was an increase in redness $\left(\mathrm{a}^{*}\right)$ value and decrease in lightness $\left(\mathrm{L}^{*}\right)$ value with an increase in colouring pigments. The $b^{*}$ value of control noodles was 8.64 and noodles with different levels of beetroot powder increased from 2.55 to 4.41 . The quantity of beetroot powder added had great effect on the colour quality of noodles samples. After three months of storage, the noodles became lighter and lost their red colouration. With such changes occurring, it was assumed that at some point in time, the noodles could become white. The colour loss could be due to oxidation of betalain in the beetroot components. Interaction of beetroot amount with storage period affected lightness ( $L^{*}$ value) of noodles. Abiodun et al.,(2017) 
stated that colour of food products is important parameter that determines the acceptability of food by the consumers.

Table 1: Effect of storage on colour of wheat-beetroot Noodles

\begin{tabular}{lllll}
\hline Sample & Month & $\mathrm{L}$ & $\mathrm{a}^{*}$ & $\mathrm{~b}^{*}$ \\
\hline BCA & 0 & $51.98 \pm 3.18^{\mathrm{b}}$ & $1.13 \pm 0.66^{\mathrm{e}}$ & $8.64 \pm 0.65^{\mathrm{a}}$ \\
& 3 & $59.93 \pm 2.43^{\mathrm{a}}$ & $0.75 \pm 0.12^{\mathrm{f}}$ & $7.48 \pm 0.45^{\mathrm{b}}$ \\
BCB & 0 & $44.21 \pm 3.23^{\mathrm{d}}$ & $5.12 \pm 0.96^{\mathrm{bc}}$ & $2.55 \pm 0.77^{\mathrm{e}}$ \\
& 3 & $49.70 \pm 1.56^{\mathrm{bc}}$ & $3.39 \pm 0.89^{\mathrm{d}}$ & $1.40 \pm 0.06^{\mathrm{f}}$ \\
BCC & 0 & $40.18 \pm 1.41^{\mathrm{e}}$ & $6.23 \pm 1.38^{\mathrm{b}}$ & $3.61 \pm 0.08^{\mathrm{d}}$ \\
& 3 & $47.82 \pm 1.24^{\mathrm{c}}$ & $4.69 \pm 0.79^{\mathrm{cd}}$ & $2.17 \pm 0.36^{\mathrm{e}}$ \\
BCD & 0 & $38.29 \pm 0.52^{\mathrm{e}}$ & $9.47 \pm 0.61^{\mathrm{a}}$ & $4.41 \pm 0.17^{\mathrm{c}}$ \\
& 3 & $46.76 \pm 0.44^{\mathrm{cd}}$ & $5.79 \pm 0.15^{\mathrm{c}}$ & $3.69 \pm 0.12^{\mathrm{d}}$
\end{tabular}

Column values with different superscript are significantly $(p<0.05)$ different.

BCA: $100 \%$ Wheat flour, BCB: 95\% Wheat flour, 5\% Beetroot powder

BCC: $90 \%$ Wheat flour, 10\% Beetroot powder, BCD: $85 \%$ Wheat flour, 15\%

Beetroot powder

\section{Proximate Composition of Wheat-Beetroot Noodles}

The results of the proximate composition of the noodles samples are shown in Table 2. The moisture content of noodle ranges from $11.2 \%$ to $8.59 \%$ with sample BCA (control sample) having the highest. All samples were within the range of the moisture contents of dried foods i.e. below $12.5 \%$ for shelf stable storability (Chakraverty, 2004). Flour and starch containing more than $12.5 \%$ moisture have less storage stability than those with lower moisture content. For this reason, a water content of not more than $12.5 \%$ is generally specified for flours and other related products (Chakraverty, 2004). Protein content was higher in sample BCD (15\% beetroot). The fat content decreases as the level of beetroot powder substitution increases ranging from $2.03 \%$ to $1.34 \%$. This could be due to low fat content of beetroot. However, the fibre content and ash content increases with the level of beetroot powder, there were significant difference between the samples. The total carbohydrate content of sample BCD had the highest value. There were significant differences between the samples. These may be as a result of the high fibre content in beetroot. 
Table 2: Proximate composition of wheat-beetroot Noodles

\begin{tabular}{llccccc}
\hline Sample & $\begin{array}{c}\text { Moisture } \\
\text { content (\%) }\end{array}$ & $\begin{array}{c}\text { Crude } \\
\text { protein (\%) }\end{array}$ & $\begin{array}{c}\text { Crude fat } \\
(\%)\end{array}$ & $\begin{array}{c}\text { Total Ash } \\
(\%)\end{array}$ & $\begin{array}{c}\text { Crude } \\
\text { fibre } \\
(\%)\end{array}$ & $\begin{array}{c}\text { Carbohydrate } \\
(\%)\end{array}$ \\
\hline BCA & $11.2 \pm 0.35^{\mathrm{a}}$ & $12.66 \pm 0.05^{\mathrm{a}}$ & $2.03 \pm 0.02^{\mathrm{a}}$ & $1.24 \pm 0.02^{\mathrm{d}}$ & $2.09 \pm 0.01^{\mathrm{d}}$ & $70.81 \pm 0.00^{\mathrm{c}}$ \\
$\mathrm{BCB}$ & $10.19 \pm 0.21^{\mathrm{b}}$ & $12.34 \pm 0.75^{\mathrm{a}}$ & $1.65 \pm 0.03^{\mathrm{b}}$ & $1.41 \pm 0.01^{\mathrm{c}}$ & $2.15 \pm 0.00^{\mathrm{c}}$ & $72.26 \pm 0.81^{\mathrm{b}}$ \\
$\mathrm{BCC}$ & $7.22 \pm 0.01^{\mathrm{d}}$ & $13.05 \pm 0.03^{\mathrm{a}}$ & $1.41 \pm 0.05^{\mathrm{c}}$ & $1.73 \pm 0.04^{\mathrm{b}}$ & $2.27 \pm 0.01^{\mathrm{b}}$ & $74.33 \pm 0.14^{\mathrm{a}}$ \\
BCD & $8.59 \pm 0.01^{\mathrm{c}}$ & $13.37 \pm 0.01^{\mathrm{a}}$ & $1.34 \pm 0.01^{\mathrm{c}}$ & $1.99 \pm 0.02^{\mathrm{a}}$ & $2.38 \pm 0.02^{\mathrm{a}}$ & $72.34 \pm 0.01^{\mathrm{b}}$ \\
\hline
\end{tabular}

Column values with different superscript are significantly $(p<0.05)$ different.

BCA: $100 \%$ Wheat flour, BCB: 95\% Wheat flour, 5\% Beetroot powder

BCC: $90 \%$ Wheat flour, 10\% Beetroot powder, BCD: $85 \%$ Wheat flour, 15\%

Beetroot powder

\section{Effect of Storage on Betalain Content of Wheat-Beetroot Noodles}

Table 3 shows the effect of storage on the betalain content of beetroot noodles. The Tables shows that the amount of betalain in beetroot was high $(98.48 \mathrm{mg} / \mathrm{l})$ than others and reduced substantially after processing. Noodles with $5 \%$ beetroot contained less betalain than noodles with $10 \%$ beetroot which is also lesser than $15 \%$. This simply implies that betalain in noodles increase significantly $(p>0.05)$ with increase in beetroot powder. Betalain content of the samples ranges from 2.09 to $3.93 \mathrm{mg} / \mathrm{l}$ before storage with sample BCD having the highest. However, the betalain content decreases with storage as a result of oxidation which leads to bleaching and reduction in the betalain contents. Temperature is also an important factor influencing betalain stability. Previous studies reported betalain degradation with increase in temperatures (Garcia-Barrera et al.,1998; Bucur et al., 2016). The betacyanins content increased significantly ( $p>0.05)$ with addition of beetroot powder with sample BCD having the highest value $(2.44 \mathrm{mg} / \mathrm{l})$. Also, the betaxanthins content increases significantly $(p>0.05)$ with addition of beetroot powder with sample BCD having the highest value $(1.49 \mathrm{mg} / \mathrm{l})$. During storage, loss of betacyanins and betaxanthins was recorded to be substantial. The values obtained during storage of noodle sample in terms of betacyanins and betaxanthins ranged from $2.44 \mathrm{mg} / \mathrm{l}$ to $0.83 \mathrm{mg} / \mathrm{l}$ and $1.49 \mathrm{mg} / \mathrm{l}$ to $0.56 \mathrm{mg} / \mathrm{l}$. Kathiravan et al., (2015) reported degradation of betaxanthin and betacyanin contents during storage. Therefore, storage reduced the stability of betalain in the wheat-beetroot noodles. 
Table 3: Effect of storage on betalain content of wheat-beetroot Noodles

\begin{tabular}{lllll}
\hline Samples & Month & $\begin{array}{l}\text { Betacyanins } \\
(\mathrm{mg} / \mathrm{l})\end{array}$ & $\begin{array}{l}\text { Betaxanthins } \\
(\mathrm{mg} / \mathrm{l})\end{array}$ & $\begin{array}{l}\text { Betalain } \\
(\mathrm{mg} / \mathrm{l})\end{array}$ \\
\hline Beetroot & & $65.47+0.13^{\mathrm{a}}$ & $33.02 \pm 0.08^{\mathrm{a}}$ & $98.48 \pm 0.21^{\mathrm{a}}$ \\
BCB & 0 & $1.18 \pm 0.12^{\mathrm{f}}$ & $0.91 \pm 0.03^{\mathrm{d}}$ & $2.09 \pm 0.14^{\mathrm{f}}$ \\
& 1 & $0.98 \pm 0.02^{\mathrm{g}}$ & $0.80 \pm 0.01^{\mathrm{e}}$ & $1.78 \pm 0.03^{\mathrm{g}}$ \\
& 2 & $0.57 \pm 0.03^{\mathrm{i}}$ & $0.46 \pm 0.02^{\mathrm{h}}$ & $1.03 \pm 0.05^{\mathrm{i}}$ \\
& 3 & $0.03 \pm 0.00^{\mathrm{j}}$ & $0.38 \pm 0.00^{\mathrm{i}}$ & $0.07 \pm 0.00^{\mathrm{j}}$ \\
$\mathrm{BCC}$ & 0 & $2.34 \pm 0.04^{\mathrm{bc}}$ & $1.47 \pm 0.00^{\mathrm{b}}$ & $3.81 \pm 0.04^{\mathrm{bc}}$ \\
& 1 & $2.19 \pm 0.02^{\mathrm{d}}$ & $1.42 \pm 0.01^{\mathrm{b}}$ & $3.60 \pm 0.04^{\mathrm{d}}$ \\
& 2 & $0.99 \pm 0.00^{\mathrm{g}}$ & $0.65 \pm 0.01^{\mathrm{f}}$ & $1.64 \pm 0.01^{\mathrm{g}}$ \\
$\mathrm{BCD}$ & 3 & $0.62 \pm 0.94^{\mathrm{i}}$ & $0.42 \pm 0.05^{\mathrm{h}}$ & $1.04 \pm 0.04^{\mathrm{i}}$ \\
& 0 & $2.44 \pm 0.02^{\mathrm{b}}$ & $1.49 \pm 0.01^{\mathrm{b}}$ & $3.93 \pm 0.04^{\mathrm{b}}$ \\
& 1 & $2.26 \pm 0.00^{\mathrm{cd}}$ & $1.47 \pm 0.06^{\mathrm{b}}$ & $3.72 \pm 0.06^{\mathrm{cd}}$ \\
& 2 & $1.93 \pm 0.08^{\mathrm{e}}$ & $1.20 \pm 0.01^{\mathrm{c}}$ & $3.13 \pm 0.09^{\mathrm{e}}$ \\
& 3 & $0.83 \pm 0.04^{\mathrm{h}}$ & $0.56 \pm 0.05^{\mathrm{g}}$ & $1.38 \pm 0.09^{\mathrm{h}}$ \\
\hline
\end{tabular}

Column values with different superscript are significantly $(p<0.05)$ different. BCB: $95 \%$ Wheat flour, 5\% Beetroot powder, BCC: $90 \%$ Wheat flour, $10 \%$ Beetroot powder

BCD: $85 \%$ Wheat flour, 15\% Beetroot powder

\section{Cooking Properties of Cooked Noodles.}

Table 4 shows the swelling power, cooking loss and the colour of the cooked noodles samples. The swelling power of the beetroot noodles showed that there were significant differences between the samples at $p<0.05$. The swelling power increased significantly with the addition of beetroot powder. Sample BCA had the least swelling power of $3.87 \%$. On addition of $5 \%$ beetroot powder, the value increased to $4.16 \%$, then to $4.57 \%$ for $15 \%$ beetroot powder. Cooking loss of solids tests the amount of residue in the cooking water. There were significant differences also in percentage cooking loss $(p<0.05)$ of the noodles. The value ranged from $5.18-11.09 \%$ with sample $B C D$ having the highest followed by sample BCC and then BCB. 
Table 4: Swelling power, the cooking loss and the colour analysis of the cooked noodles

\begin{tabular}{llllll}
\hline Sample & Swelling power & Cooking loss $(\%)$ & Colour of $\mathrm{L}^{\star}$ & ${\text { Cooked } \mathrm{a}^{*}}^{\text {noodles } \mathrm{b}^{*}}$ \\
\hline BCA & $3.87 \pm 0.06^{\mathrm{d}}$ & $5.18 \pm 0.05^{\mathrm{d}}$ & $49.28 \pm 2.76^{\mathrm{a}}$ & $2.15 \pm 0.03^{\mathrm{b}}$ & $7.67 \pm 0.50^{\mathrm{a}}$ \\
BCB & $4.16 \pm 0.06^{\mathrm{c}}$ & $9.21 \pm 0.02^{\mathrm{c}}$ & $36.50 \pm 2.11^{\mathrm{c}}$ & $2.88 \pm 0.69^{\mathrm{ab}}$ & $2.75 \pm 0.94^{\mathrm{c}}$ \\
BCC & $4.39 \pm 0.01^{\mathrm{b}}$ & $10.55 \pm 0.03^{\mathrm{b}}$ & $38.91 \pm 0.62^{\mathrm{c}}$ & $3.11 \pm 0.49^{\mathrm{a}}$ & $3.09 \pm 0.30^{\mathrm{c}}$ \\
BCD & $4.57 \pm 0.04^{\mathrm{a}}$ & $11.09 \pm 0.05^{\mathrm{a}}$ & $41.50 \pm 0.29^{\mathrm{b}}$ & $3.22 \pm 0.08^{\mathrm{a}}$ & $4.30 \pm 0.50^{\mathrm{b}}$ \\
\hline
\end{tabular}

Column values with different superscript are significantly $(p<0.05)$ different.

BCA: 100\% Wheat flour, BCB: $5 \%$ Beetroot powder, 95\% Wheat flour, BCC: $10 \%$ Beetroot powder, 90\% Wheat flour, BCD: 15\% Beetroot powder, 85\% Wheat flour

Sample BCA had cooking loss of $5.18 \%$ but increased as the amount of beetroot powder increased. It has been observed that short cooking time with less soluble solid are the desirable quality of a good noodle (Sirichokworrakit et al.,2015). Chhikara et al., (2018) explained that the cooking loss was as a result of weakening or disruption of the protein-starch matrix and an uneven spreading of water within the matrix due to the presence of beetroot powder. Due to this, more solid were leached out from noodles into the cooking water. The same trend was observed in cooking loss of noodles substituted with banana flour (Taneya et al., 2014). Therefore, the more the beetroot powder level, the more the loss likely to occur while cooking.

The colours of the cooked beetroot noodles were also significantly different $(p<$ $0.05)$ with the control having the highest lightness $\left(L^{*}\right)$ value $(49.28)$ which indicated brighter colour than the wheat-beetroot noodles. The $L^{*}$ value with different levels of beetroot powder ranged from 36.50 to 41.50 . There were no significant differences $(p<0.05)$ between sample BCB, BCC and BCD in redness $\left(a^{*}\right)$ values. Sample BCA had the highest yellowness $\left(b^{*}\right)$ value $(7.67)$ which was significantly different $(p<0.05)$ from the beetroot substituted noodles. Noodles with $15 \%$ beetroot presented higher $a^{*}$ and $b^{*}$ values due to incorporation of high amount of beetroot. Kong et al. (2012) and Koca et al. (2018) also observed colour improvement in noodles enriched with black rice bran, grapes and pomegranate. Park and Baik (2004) and Eyidemir and Hayta, (2009) reported increase in $b^{*}$ value of green tea powder and apricot seed flour substituted noodles. According to Ravichandran et al., (2013), colour is a quality indicator 
that determines consumer acceptability of foods. Addition of beetroot powder impacted the colour characteristics on the noodles.

\section{Effect of Storage on the Antioxidant Property of Beetroot Noodle}

The antioxidant property of beetroot noodles is shown in Fig. 1. Noodle with $15 \%$ beetroot flour had higher antioxidant value of $39.22 \%$. Control had the least value of $25.67 \%$. Antioxidant properties of the noodles increased with increase in beetroot powder addition. However, at 3 months of storage, there were reductions in the antioxidant properties of all the noodles. Sample BCD have the highest value due to the highest percentage of beetroot powder (15\%). Incorporation of beetroot powder substantially improved antioxidant activity of studied noodle. Decrease in antioxidant activities of the noodles during storage was also observed by Kathiravan et al. (2015). Ravichandran et al. (2013) suggested that increase in antioxidants in treated beetroot samples may not be due to presence of betalain alone but also on other polyphenols present in the samples.

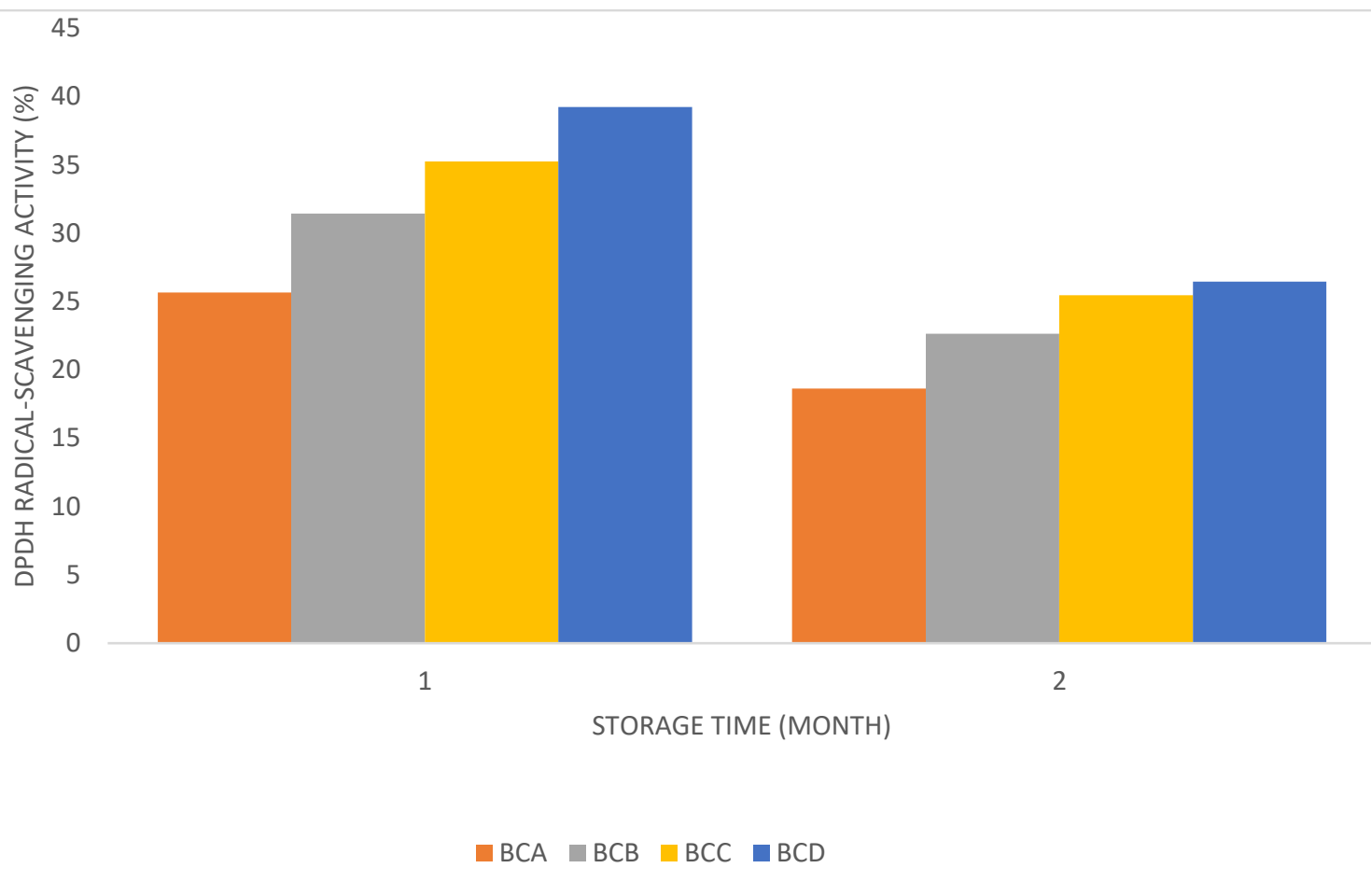

Fig 1: Effect of storage on the antioxidant property of Beetroot noodles 


\section{Sensory Properties of Wheat-Beetroot Noodles}

The result of sensory evaluation is presented in Table 5 . The result reveals that the sensory score for appearance of cooked noodles improved with incorporation of beetroot powder. Sample BCA was significantly different $(p<0.05)$ in appearance from the beetroot substituted noodles. But there were no significant differences $(p>0.05)$ in the appearance of the beetroot substituted noodles. There were no significant differences $(p>0.05)$ in the taste, aroma, texture and overall acceptability of all the noodles. The appearance of the sample with $100 \%$ wheat flour was preferred over the samples containing beetroot powder.

Table 5: Sensory properties of wheat-beetroot noodles

\begin{tabular}{llllll}
\hline Samples & Taste & Appearance & Aroma & Texture & $\begin{array}{l}\text { Overall } \\
\text { acceptability }\end{array}$ \\
\hline BCA & $6.25 \pm 1.45^{\mathrm{a}}$ & $6.85 \pm 0.99^{\mathrm{a}}$ & $5.60 \pm 1.27^{\mathrm{a}}$ & $6.15 \pm 1.23^{\mathrm{a}}$ & $5.85 \pm 2.25^{\mathrm{a}}$ \\
BCB & $6.10 \pm 1.41^{\mathrm{a}}$ & $5.55 \pm 1.50^{\mathrm{b}}$ & $5.65 \pm 1.14^{\mathrm{a}}$ & $5.80 \pm 1.24^{\mathrm{a}}$ & $5.85 \pm 1.63^{\mathrm{a}}$ \\
BCC & $6.00 \pm 1.41^{\mathrm{a}}$ & $5.60 \pm 1.73^{\mathrm{b}}$ & $5.40 \pm 1.05^{\mathrm{a}}$ & $6.05 \pm 1.32^{\mathrm{a}}$ & $5.95 \pm 1.85^{\mathrm{a}}$ \\
BCD & $6.00 \pm 1.17^{\mathrm{a}}$ & $4.95 \pm 1.79^{\mathrm{b}}$ & $5.65 \pm 0.93^{\mathrm{a}}$ & $6.05 \pm 1.19^{\mathrm{a}}$ & $5.65 \pm 1.79^{\mathrm{a}}$ \\
\hline
\end{tabular}

Column values with different superscript are significantly $(p<0.05)$ different. BCA: 100\% Wheat flour, BCB: 95\% Wheat flour, 5\% Beetroot powder, BCC: 90\% Wheat flour, 10\% Beetroot powder, BCD: 85\% Wheat flour, 15\% Beetroot powder

\section{CONCLUSION}

Substitution of beetroot powder increased the betalain content of the noodles but substantially reduced during storage. Also, the redness of the noodles fades as a result of oxidation during the storage period. However, cooking loss increased with incorporation of beetroot powder; the higher the beetroot powder, the higher the cooking loss. The highest redness colour of cooked noodles was obtained in sample BCB while the lightest was sample BCD. The antioxidant level of the noodles reduced during the storage period with sample BCD having the highest value. There were no significant differences $(p>0.05)$ in the taste, aroma, texture 
and overall acceptability of the noodles, but the appearance of sample BCA was more preferred.

\section{REFERENCES}

American Association of Cereal Chemists (2000). Approved Methods of the American Association of Cereal Chemists, (10 ${ }^{\text {th }} \mathrm{ed}$. pp. 914-918). AACC, St. Paul, MN, USA.

Abiodun, O.A., Akinoso, R. and Dauda, A.O. (2017). Evaluation of colour in white and yellow trifoliate yam flours in relation to harvesting periods and preprocessing methods. Agrosearch,17 (1), 1-10.

Abiodun, O.A., Dauda, A.O., Opaleke, D.O., Ojo, A., Adekoyeni, O.O. and Aransiola, F.T. (2017). Effect of yellow trifoliate yam flour substitution on the colour, carotene and cooking properties of wheat noodles. Nigerian Journal of Agriculture, Food and Environment, 13(2), 169-173.

Abiodun, O.A., Dauda, A.O., Oluoti, O.J., Adepeju, A.B., Ojo, A., Mustapha, A. and Ogueyungbo, A.O. (2018). Quality attributes of stored wheat-carrot noodles. Proceedings of $4^{\text {th }}$ Regional Food Science and Technology Submit (REFOSTS), Enujiugha, V.N and Jolayemi, O (eds), held at Akure, Ondo State, Nigeria, from $6^{\text {th }}-7^{\text {th }}$ June, 2018.

Association of Official Analytical Chemist, (2010). Official methods of analysis, Association of official analytical chemist (19th ed.) Washington D.C., USA.

Animashahun, R. A, Omoikhoje, S. O, Alabi, O.O, Shoyombo, A.J. and Olawoye, S.O. (2018). Influence of graded levels of instant noodle waste in the diets on the performance, carcass traits and haematology of broiler chickens. Agrosearch, 18 (1), 40 - 52.

Bucur, L., Taralunga, G. and Schroder, V. (2016). The betalains content and antioxidant capacity of red beet (Beta vulgaris L. Subsp. Vulgaris) root. Farmacia, 64 (2),198-201.

Chakraverty, A. (2004). Post-Harvest of Oil Seeds. Oxford and IBH Publishing Company, Pvt. Ltd, New Delhi, India.

Chhikara, N. Kushwaha, K., Jaglan, S., Sharma, P. and Panghal, A. (2018). Nutritional, physicochemical, and functional quality of beetroot (Beta vulgaris L.) incorporated Asian noodles. Cereal Chemistry, 96 (1), 154161.

Dhiraj,B. and Prabhasankar, P. (2013). Influence of Wheat-Milled Products and their Additive Blends on Pasta Dough Rheological, Microstructure, and 
Product Quality Characteristics. International Journal of Food Science, 13, 1-10.

Eyidemir, E., and Hayta, M. (2009). The effect of apricot kernel flour incorporation on the physicochemical and sensory properties of noodle. African Journal of Biotechnology, 8(1), 85-90.

Garcia-Barrera, F. A., Reynoso, C. R., and Gonzalez de Mejia, E. (1998). Stability of betalains extracted from garambullo (Myrtillocactus geometrizans). Journal of Food Science and Technology International, 4,115-120.

Hou, G. and Kruk, M. (1998). Asian noodle technology. Technical Bulletin, XX(12), 1-10.

Kathiravan, T., Nadanasabapathi, S. and Kumar, R. (2015). Pigments and antioxidant activity of optimized ready to drink (RTD) beetroot (Beta vulgaris L.)-passion fruit (Passiflora edulis var. Flavicarpa) juice blend. Croatian Journal of Food Science and Technology, 7(1), 9-21.

Koca, I., Tekguler, B., Yilmaz, V.A., Hasbay, I. and Koca, A.F. (2018). The use of grape, pomegranate and rosehip seed flours in Turkish noodle (erişte) production. Journal of Food Processing and Preservation, 42(1), e13343, 1-12.

Kong, S., Kim, D. J., Oh, S. K., Choi, I. S., Jeong, H. S., and Lee, J. (2012). Black rice bran as an ingredient in noodles: chemical and functional evaluation. Journal of Food Science, 77(3), $303-307$.

Nooraziah, A.A. and Komathi, C. A. (2009). Acceptability attributes of crackers made from different types of composite flour. International Food Research Journal, 16(4), 479-482.

Noorfarahzilah, M., Lee, J. S., Sharifudin, M. S., MohdFadzelly, A. B. and Hasmadi, M. (2014). Applications of composite flour in development of food products. International Food Research Journal, 21(6), 2061-2074.

Omeire, G.C., Nwosu, J.N., Kabuo, N.O. and Nwosu, M. O. (2015). Cooking properties and sensory evaluation of enriched cassava/wheat noodles. International Journal of Innovative Research in Technology \& Science, 3(2), 46-50.

Oyeyinka, S. A., Adeloye, A. A.., Smith, S. A., Adesina, B. O., and Akinwande, F. F. (2019). Physicochemical properties of flour and starch from two cassava varieties. Agrosearch, 19(1), 28-45.

Park, C. S., and Baik, B. K. (2004). Cooking time of white salted noodles and its relationship with protein and amylose contents of wheat. Journal of Cereal Chemistry, 81, 165-171. 
Ravichandran, K., Saw, N. M. M. T., Mohdaly, A. A., Gabr, A. M., Kastell, A., Riedel, H., andSmetanska, I. (2013). Impact of processing of red beet on betalain content and antioxidant activity. Journal of Food Research International, 50(2), 670-675.

Sanni, L. O., Banigdose, C. A. and Sanni, S. A. (2004). Production of instant cassava noodles. Journal of Food Technology, 2(2), 83-89.

Sirichokworrakit, S., Phetkhut, J. and Khommoon, A. (2015). Effect of partial substitution of wheat flour with rice berry flour on quality of noodles. Procedia-Social and Behavioural Sciences,197,1006-1012

Taneya, M.L.J., Biswas, M.M.H. and Shams-Ud-Din, M. (2014). The studies on the preparation of instant noodles from wheat flour supplementing with sweet potato flour. Journal of the Bangladesh Agricultural University,12(1), 135-142. 